\section{The habit of buying foods announced on television increases ultra-processed products intake among schoolchildren}

\author{
O hábito de comprar produtos alimentícios \\ anunciados na televisão aumenta o consumo de \\ alimentos ultraprocessados por escolares
}

\author{
El hábito de comprar comidas anunciadas en \\ anuncios de televisión incrementa la ingesta de \\ productos ultraprocesados entre escolares
}

Raphaela Silveira Fraga 1

Sarah Liduário Rocha Silva 1 Luana Caroline dos Santos 1 Luana Rosa de Oliveira Titonele 2 Ariene da Silva Carmo 1

doi: 10.1590/0102-311X00091419

\begin{abstract}
This study aimed to verify the effects of buying television advertised food in schoolchildren eating behaviors. We performed a cross-sectional study with fourth grade students of an elementary education in Belo Horizonte, Minas Gerais State, Brazil. We analyzed anthropometric data, the habit of buying television advertised food/beverages, and food consumption (two 24-hour dietary recalls). Logistic regression models were conducted and adjusted for gender, age, caloric intake, nutritional status, and social deprivation of area of residence. In total, 797 children were evaluated, the mean age was 9.81 (0.59) years, $50.7 \%$ were female, and $32.4 \%$ overweight. The prevalence of the habit of buying television advertised food was $43.1 \%$, among which $99.3 \%$ concerned ultra-processed foods, according to the classification proposed by Monteiro et al. (2016), mainly milk beverages (12.1\%), industrialized biscuits (11.5\%) and candies (9.5\%). The habit of buying advertised food increased the chance of consuming ultra-processed foods (OR = 1.92; 95\%CI: 1.06-3.46). We found no correlation between this habit and the consumption of minimally processed and processed foods $(p<0.05)$. This study findings may corroborate the debate on food advertising policy and the development of effective nutrition interventions among schoolchildren, which should involve integrated education bringing together children and parents.
\end{abstract}

Food Consumption; Food Publicity; Child; Television

\author{
Correspondence \\ R. S. Fraga \\ Universidade Federal de Minas Gerais. \\ Av. Prof. Alfredo Balena 190, 30 andar, sala 324, Belo Horizonte, \\ MG 30130-100, Brasil. \\ raphaela.bh@hotmail.com \\ 1 Universidade Federal de Minas Gerais, Belo Horizonte, Brasil. \\ 2 Secretaria Municipal de Assistência Social, Segurança \\ Alimentar e Cidadania, Prefeitura de Belo Horizonte, Belo \\ Horizonte, Brasil.
}

(1)




\section{Introduction}

Television (TV) is the main communication vehicle, especially among lower-income populations, capable of transmitting information from education to entertainment 1 . Watching TV is the dominant recreational pastime of all age groups, especially among children and adolescents 2.

In Brazil, 79.5\% of ninth grade schoolchildren watch TV for two or more hours a day 3 . In Europe, recent evidence shows that children aged between 10 and 12 years spend on average 3.5 hours a day in front of the TV 4. Both estimates exceed the recommended screen time of up to two hours per day 5.

A study that analyzed the composition of foods advertised during children's TV programming found that $50 \%$ of the products were high in sugar. The main food items advertised, both on weekends and weekdays, were soft drinks, yogurts, fermented beverages and cookies ${ }^{6}$. A descriptive study on the adequacy of food commercials directed to children by six pay-TV broadcasters in Brazil reported that all channels advertised mostly ultra-processed foods, whereas no fresh food advertisements were observed $(\mathrm{p}<0.001) 7$.

Dietary patterns have been changing worldwide and ultra-processed food consumption have increased among both adults and children 8 . Ultra-processed foods are industrial formulations that are ready-to-eat or ready-to-heat. Its consumption is problematic not only because they are high in added sugars, salt and/or saturated fatty acids, but also because they contain several food additives -flavor enhancers, flavoring and coloring agents, and preservatives - making them palatable, convenient and affordable to encourage purchase and consumption 9 .

Despite being associated to several health outcomes in adults, such as overweight and obesity 10 , the excessive consumption of ultra-processed products also affects children. Earlier studies have shown that ultra-processed food consumption is associated with higher waist circumference and abdominal obesity in children 11 , as well as higher LDL and total cholesterol from preschool to school age 12 .

TV advertising seems to influence children's food preferences. A recent systematic review underlined TV advertising influence on food and beverage preferences of children between 2 and 11 years old 13. Consumers are making decisions regarding food at a much younger age, either by influencing parents and guardians or by making independent purchase decisions ${ }^{14}$. A study with 347 children aged between 3 and 8 years revealed that $40.3 \%$ of them asked their parents to buy food products they saw on TV advertisements, and that $8.9 \%$ argued or cried to persuade their parents to buy a particular food or drink 15 .

Considering children's vulnerability to TV-transmitted information, excessive screen time and exposure to food and beverage advertising can impair food consumption and induce overweight, obesity and other chronic non-communicable diseases (NCDs), such as diabetes, systemic arterial hypertension, cardiovascular diseases, besides affecting early childhood growth and development 16,17.

Few studies explore ultra-processed consumption through the association between children's habit of buying food, the TV and food consumption, and outcomes are still controversial 18,19. Martines et al. 18 conducted a study in the United Kingdom assessing the correlation between TV viewing and ultra-processed food consumption by children (4-10 years) and found that the highest daily intake of ultra-processed foods is associated with eating while watching TV. In China, a study aimed to examine the association between watching TV and commercials and the habit of buying, ordering and snacking while watching TV among young Chinese (6-18 years). Individuals that reported paying attention to commercials were more likely to order and buy food advertised on TV. However, TV-viewing frequency was not significantly correlated with snacking 19.

In this context, this study aimed to verify the association between the habit of buying TV advertised food and ultra-processed food consumption among schoolchildren. 


\section{Methods}

\section{Study sample and design}

This is a cross-sectional study conducted with fourth grade students, with mean age of 10 years old from municipal schools of Belo Horizonte, Minas Gerais State, Brazil, invited to participate in the research project Integrated Actions for Food and Nutrition Education in Municipal Educational Units: Promotion of Health, and Food and Nutrition Security (Ações Integradas de Educação Alimentar e Nutricional em Unidades Educacionais Municipais: Promoção de Saúde e da Segurança Alimentar e Nutricional). This study was performed in partnership with the Department of Nutrition of the Minas Gerais State Federal University (UFMG), the Sub-secretariat for Food and Nutrition Security (SUSAN) and the Department of Education (SMED) of the Belo Horizonte City Council (PBH). Data were collected during 2014 and 2015.

The sample $(\mathrm{n}=371)$ was estimated from data provided by SMED and SUSAN. According to Hulley \& Cummings' criteria 20 , we considered a 50\% proportion for a supplied characteristic, which provides the largest sample size for the finite population (total population $=10,623$ ), a 5\% significance level (alpha or type I error), and 5\% sample error. This value was further multiplied by two, for comprising a complex sampling design of two-stage cluster sampling (schools and grades), stratified by region. The values $(\mathrm{n}=742)$ were proportionally distributed according to each region size (the nine Belo Horizonte regions). Each of the nine administrative regions of the municipality selected and stratified 17 schools by one-stage cluster sampling.

In total, 931 students in the fourth grade were invited to participate in the study, among which were excluded those who were absent for data collection $(n=101)$, refused to participate in the survey $(n=2)$ or those who teachers reported presenting mental disorders $(n=31)$. Regarding gender, age and area of residence, excluded schoolchildren did not present statistically significant differences from those included ( $\mathrm{p}>0.05$ ). 797 students formed the final sample.

The research protocol was approved by the Ethics Research Committee of the UFMG (CAAE 00734412.0.0000.5149). Respecting the dignity and integrity of all study subjects, all mothers or guardians of schoolchildren in this study signed an informed consent form agreeing with the participation of their children in the project.

\section{Data collection and study variables}

Demographic information, such as gender, address, and date of birth, were collected from school records.

Duly trained dietitians and nutrition students, supervised by the main researcher, conducted a face-to-face questionnaire in children's respective school units to investigate their eating habits, food consumption and anthropometric profile.

Children's habit was assessed by the qualitative question: "Do you have the habit of buying TV advertised foods?". If the answer was positive, the researchers requested the children to describe the purchased food and then classified it according to the degree of processing.

Screen time was evaluated by the question: "How much time a day do you spend in front of the TV, computer or cell phone?". The answer was classified as adequate ( $\leq 2$ hours/day) or inadequate time ( $>2$ hours/day) 5 .

Regarding food consumption, two 24-hour dietary recalls (24hR) on non-consecutive days were applied face-to-face by trained dietitians. Children reported all foods and beverages consumed at or away from school in quantity and type of preparation. Participants used real cooking measuring tools (such as spoons, cups, and glasses) to report the amount of food consumed. As for food preparations, according to measures reported by children, recipe ingredients were dismembered and the caloric value was determined based on the proportions of the same ingredients in recipe books and websites.

Data on children food/beverage consumption, obtained by the average consumption resulting of the two dietary recalls, were analyzed in line with the Brazilian Institute of Geography and Statistics (IBGE) methodology for the management of food consumption data of the 2008/2009 Brazilian National Household Budget Survey (POF, acronym in Portuguese). To analyze the nutritional content of 
children's diet, we used a food composition table designed for Brazilian dietary surveys 21. Food and caloric intake were estimated based on a food composition table 22 and a measures of food consumption table 23 for foods consumed in Brazil. The researchers included in the analysis foods and beverages reported by children that lacked in this table.

The analysis gathered information on caloric intake and the percentage of total calories for ultraprocessed, processed and minimally processed foods, following Monteiro et al. 24 food classification (NOVA), which categorizes food according to the extent and purpose of their processing.

NOVA minimally processed foods are in natura foods subjected to cleaning, removal of inedible parts, drying, packaging, pasteurizing, freezing, refining or fermentation. Processed foods are industrialized food with the addition of salt or sugar to make them durable, palatable and more appealing, for example canned vegetables, canned fruit in syrup, and cheese. Ultra-processed foods are industrial formulations made from oils, fats, sugar, proteins, colorants, flavorings, flavor enhancers and other additives to give the final product attractive sensory properties. They are: sweet cookies and crackers, chips, cereal bars, sweets in general, fast-food snacks, instant noodles, several ready-made or semiprepared meals, and soft drinks 24 .

We classified foods according to the degree of processing and quantified their consumption as percentage contribution to total energy intake (\% total caloric value - TCV), which was classified as lower, greater or equal to the 80th percentile.

Regarding anthropometric profile, we employed the Food and Nutrition Surveillance System (SISVAN) to measure weight and height. These data were used to calculate the body mass index $\left(\mathrm{BMI}=\operatorname{weight}(\mathrm{kg}) /\right.$ height $\left.(\mathrm{m})^{2}\right)$, which was further classified according to SISVAN criteria, based on the World Health Organization (WHO) growth standards 25,26.

\section{Statistical analysis}

Data were processed by Epi Info, version 3.4.5 (https://www.cdc.gov/epiinfo/index.html), with double-entry, which enabled the due analysis of consistency.

We calculated frequency distributions, measures of central tendency and dispersion. The ShapiroWilk test was used to evaluate the normality of the quantitative variables.

Chi-square test was performed to verify the relationship between socio-demographic factors, healthy habits and the habit of buying TV advertised foods.

Logistic regression models were used to test the influence of the habit of buying TV advertised food on ultra-processed, processed and minimally processed food consumption. In each model, we adopted as dependent variable the highest quintile of consumption within one of these food groups. Models were adjusted for child's gender, age, nutritional status, caloric intake and screen time. Odds ratio (OR) with $95 \%$ confidence interval $(95 \% \mathrm{CI})$ was used as relative measure of effect.

We analyzed the data using Stata software, version 12.0 (https://www.stata.com). All analyses considered the sampling plan by means of the Stata command "svy" and a 5\% significance level.

\section{Results}

This study evaluated 797 students with mean age of $9.81(0.59)$ years, among which $50.7 \%$ were female and $32.4 \%$ overweight. $43.1 \%$ reported the habit of buying TV advertised food: $0.7 \%$ buys fruits, vegetables, meat, and milk; and $99.3 \%$ buys ultra-processed foods. We found no significant difference in the prevalence of this habit considering socio-demographic data, nutritional status and screen time $(\mathrm{p}>0.05)$ (Table 1).

The most purchased ultra-processed foods were dairy beverages (12.1\%), cookies (11.5\%) and sweets in general (9.5\%) (Figure 1).

Individuals with the habit of buying TV advertised showed 1.92 times (95\%CI: 1.06-3.46) more chance to consume ultra-processed foods; it did not influence processed foods ( $\mathrm{OR}=0.72$; 95\%CI: 0.41-1.28) and minimally processed foods consumption (OR = 0.82; 95\%CI: 0.45-1.49) (Table 2). 
Table 1

Distribution of the habit of buying television advertised food according to socio-demographic data, nutritional status and screen time among schoolchildren. Belo Horizonte, Minas Gerais State, Brazil, 2014-2015.

\begin{tabular}{|c|c|c|c|c|}
\hline \multirow[t]{2}{*}{ Variable } & \multirow[t]{2}{*}{ Total (\%) } & \multicolumn{2}{|c|}{$\begin{array}{l}\text { Habit of buying television advertised } \\
\text { food }\end{array}$} & \multirow[t]{2}{*}{ p-value } \\
\hline & & Yes (\%) & No $(\%)$ & \\
\hline Gender & & & & 0.733 \\
\hline Female & 50.7 & 50.0 & 51.2 & \\
\hline Male & 49.3 & 50.0 & 48.8 & \\
\hline Age range (years) & & & & 0.646 \\
\hline Between 8 and 9 & 73.5 & 74.3 & 72.8 & \\
\hline 10 and older & 26.5 & 25.7 & 27.2 & \\
\hline Screen time & & & & 0.765 \\
\hline Adequate ( $\leq 2$ hours) & 51.2 & 50.6 & 51.7 & \\
\hline Inadequate (> 2 hours) & 48.8 & 49.4 & 48.3 & \\
\hline Body mass index & & & & 0.679 \\
\hline Normal weight & 67.6 & 66.7 & 68.9 & \\
\hline Overweight & 32.4 & 33.3 & 31.1 & \\
\hline
\end{tabular}

\section{Figure 1}

Percentage distribution of ultra-processed foods purchased by schoolchildren with the habit of buying television advertised food/beverages. Belo Horizonte, Minas Gerais State, Brazil, 2014-2015.

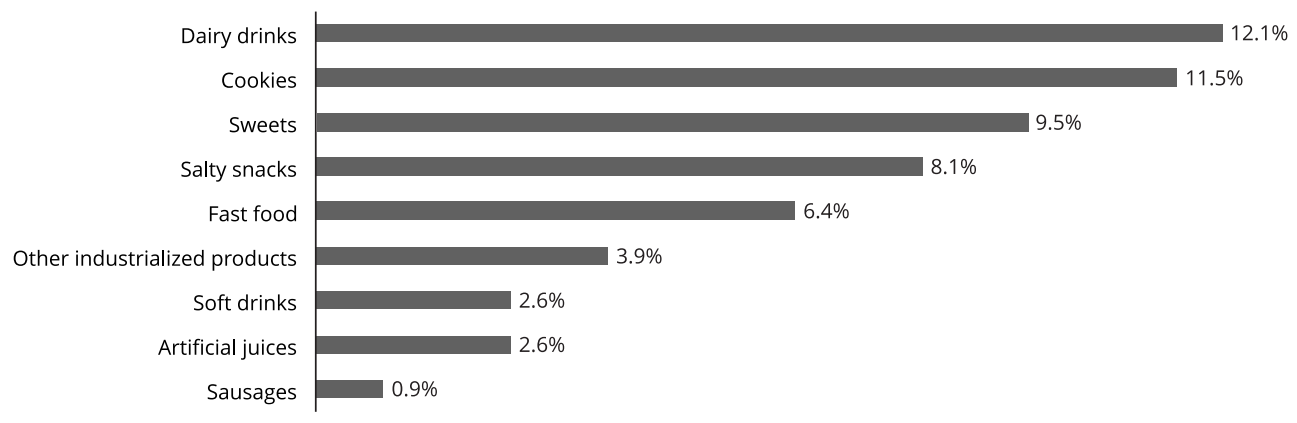


Table 2

Multiple logistic regression models for predicting ultra-processed, processed and minimally processed food consumption based on the habit of buying television advertised foods by schoolchildren. Belo Horizonte, Minas Gerais State, Brazil, 2014-2015.

\begin{tabular}{|c|c|c|c|c|c|c|}
\hline \multirow[t]{3}{*}{ Explanatory variable } & \multicolumn{6}{|c|}{ Dependent variable } \\
\hline & \multicolumn{2}{|c|}{ Ultra-processed } & \multicolumn{2}{|c|}{ Processed } & \multicolumn{2}{|c|}{ Minimally processed } \\
\hline & OR raw $(95 \% \mathrm{Cl})$ & p-value & OR raw $(95 \% \mathrm{Cl})$ & p-value & OR raw $(95 \% \mathrm{Cl})$ & p-value \\
\hline \multicolumn{7}{|l|}{$\begin{array}{l}\text { Habit of buying television } \\
\text { advertised foods }\end{array}$} \\
\hline No & 1.00 & - & 1.00 & - & 1.00 & - \\
\hline \multirow[t]{2}{*}{ Yes } & $1.44(1.01-2.06)$ & 0.041 & $0.74(0.51-1.07)$ & 0.115 & $0.91(0.63-1.30)$ & 0.619 \\
\hline & $\begin{array}{l}\text { OR adjusted * } \\
\qquad(95 \% \mathrm{Cl})\end{array}$ & p-value & $\begin{array}{l}\text { OR adjusted * } \\
\qquad(95 \% \mathrm{Cl})\end{array}$ & p-value & $\begin{array}{l}\text { OR adjusted * } \\
\qquad(95 \% \mathrm{Cl})\end{array}$ & p-value \\
\hline \multicolumn{7}{|l|}{$\begin{array}{l}\text { Habit of buying television } \\
\text { advertised foods }\end{array}$} \\
\hline No & 1.00 & - & 1.00 & - & 1.00 & - \\
\hline Yes & $1.92(1.06-3.46)$ & 0.030 & $0.72(0.41-1.28)$ & 0.275 & $0.82(0.45-1.49)$ & 0.515 \\
\hline \multicolumn{7}{|c|}{ 95\%Cl: 95\% confidence interval; OR: odds ratio. } \\
\hline \multicolumn{7}{|c|}{$\begin{array}{l}\text { Note: dependent variables of each model: ultra-processed food consumption }(0:<p 80 ; 1: \geq p 80) \text {, processed food consumption }(0:<p 80 ; 1: \geq p 80) \text { and in } \\
\text { natura/minimally processed food consumption }(0:<p 80 ; 1: \geq p 80) \text {. } 80 \text { percentile of ultra-processed, processed and in natura/ minimally processed food } \\
\text { consumption: } 37.8 \%, 14.3 \% \text { and } 67.7 \% \text { of total caloric value, respectively. }\end{array}$} \\
\hline
\end{tabular}

\section{Discussion}

This study revealed a high prevalence of the habit of buying TV advertised food among schoolchildren; in particular ultra-processed foods, which favored their consumption. This may be a result of the outnumbered ultra-processed food advertisements in TV programs.

An analysis, performed in 2014, on the programs of the four most popular Brazilian TV channels showed that $60.7 \%$ of advertisements are from ultra-processed foods 27 . Costa et al. 28 analyzed the types of foods advertised in Brazilian open TV during children programs and found a predominance of "sugars and sweets" (48.1\%) and "oils, fats and oilseeds" products (29.1\%). Studies performed in other countries found similar content of food advertisements in TV programs 29,30.

The high prevalence of food advertising and its correlation with greater ultra-processed food consumption denote the potential influence of TV marketing on children requests and food choices, consumption and preferences. Schoolchildren are unable to perceive advertisements persuasiveness and thus set a vulnerable target audience, influencing on the types of food purchased by their parents 31 .

Scapin et al. investigated children's influence on household food purchase: among the 187 interviewed parents, nearly all $(\mathrm{n}=181)$ reported purchasing food at the request of their children, especially ultra-processed foods ( $84.3 \%$ of purchases) 32 .

TV advertising may arouse the interest not only in buying, but also in consuming a given food, as showed in this and other studies 12,33. An experimental study conducted with children aged between 11 and 13 years showed that, regardless of nutritional statues, TV exposure induced preference for name brands advertised food 33 . Harris et al. 34 found that children who are more exposed to advertisements consume about $45 \%$ more food than those who are not. The authors also identified that advertisement may increase advertised food consumption as well as other foods, unrelated to hunger or other influence factors of consciousness 34 .

The influence of advertisement on ultra-processed foods consumption is worrisome, as it has been positively associated with dyslipidemia among children 12 and obesity at all ages 35 . 
The Pan American Health Organization (PAHO) addresses children's vulnerability to TV advertising primarily because of ultra-processed food predominance. PAHO strongly recommends that countries in the region of the Americas implement policies to reduce children exposure to unhealthy food advertisements 36 .

A study performed in the United States showed that banning the advertising of unhealthy food could reduce caloric intake, and consequently childhood obesity and overweight rates 37 .

The Brazilian government formulated a proposal for a Technical Regulation (CP n. 71/2006) for advertising directed at children; it consists in controlling the offer, advertising, publicity, information, and other practices that target disseminating or promoting foods high on sugar, trans fat and sodium, and low-nutritional beverages 38 .

Yet, a study performed in Brazil, in 2008, found all products advertisements to be abusive, once they infringed at least three articles of the proposed Technical Regulation ${ }^{39}$. The authors stress that society in general, educators, and health professionals must reiterate the demand for ethical advertisement and for TV advertisements focused on healthy eating habits. Government interventions for protecting the public should not be seen as a restriction on freedom of expression, but rather as instruments to ensure the right to adequate and healthy food 39.

This study presents some limitations such as sample homogeneity regarding socioeconomic aspects, as we evaluated solely public-school students. For comprising a cross-sectional design, we could not infer causality. Furthermore, we did not investigate the number of, and children exposure to, food advertising and its association with ultra-processed foods consumption. Screen time effect on the habit of buying TV advertised food is usually underestimated; however, our study suggested that children with this habit are more likely to influence their parents or guardians to purchase ultraprocessed foods.

Regarding methodology, the main question used to evaluate visual media role in purchasing food items presented some limitations: the result was inferred based on the fact that purchasing and consumption are related, but to what extent TV and other vehicles influence children's purchases and preferences is still unclear.

In view of the lack of a gold standard to evaluate food consumption, $24 \mathrm{hR}$ might have implied some limitations: for disregarding day-to-day variation it must be replicated several times or a statistical method to estimate the usual intake should be applied alongside for it to be considered reliable. Although we applied this method twice, data could still be biased due to food consumption in atypical occasions. Furthermore, dietary recall is memory-dependent and therefore respondents may have over or underreported healthy/unhealthy food consumption, or poorly estimated portion sizes. We attempted to minimize this type of bias and collect more accurate information on portion sizes by presenting pictures and cooking items.

This study is relevant as few studies in the literature associate the effects of exposure to TV advertisement, the habit of buying TV advertised food, and their consumption. It also innovated by adopting the recent food classification according to the extent and purpose of their processing. Our findings denote the importance of regulating TV advertisements and developing interventions to promote greater critical awareness regarding them among both children and their parents, who are responsible for the household food purchase.

Future researches should investigate the relationship between TV exposure, advertising, and food purchase, besides addressing parents about children influence on food purchase to better understand media impact on children's food intake.

\section{Conclusion}

This study results may corroborate the debate on food advertising policies, as well as assist the development of effective nutritional interventions among schoolchildren, such as food and nutrition education, involving mainly parents, as they are in large part responsible for children's access to food.

Regardless of time period, regulating food advertisements is crucial as most of them announce ultra-processed foods, which excessive consumption can have harmful effects on health. 


\section{Contributors}

R. S. Fraga and S. L. R. Silva participated in the writing and development of the article. L. C. Santos contributed in the review and final approval of the manuscript. L. R. O. Titonele reviewed the manuscript. A. S. Carmo participed in the statistical analysis and reviewed the manuscript.

\section{Additional informations}

ORCID: Raphaela Silveira Fraga (0000-0002-00870116); Sarah Liduário Rocha Silva (0000-00025499-8131); Luana Caroline dos Santos (00000001-9836-3704); Luana Rosa de Oliveira Titonele (0000-0002-1691-9447); Ariene da Silva Carmo (0000-0002-3421-9495).

\section{Acknowledgments}

We are thankful to all colleagues who have helped us from collecting data to revising the manuscript. We also thank the revisors for all comments and suggestions to improve our article.

\section{References}

1. Almeida SS, Nascimento PCBD, Quaioti TCB. Amount and quality of food advertisement on Brazilian television. Rev Saúde Pública 2002; 36:353-5.

2. Swinburn B, Shelly A. Effects of TV time and other sedentary pursuits. Int J Obes 2008; 32:132-6.

3. Levy RB, Castro IRR, Cardoso LO, Tavares LF, Sardinha LMV, Gomes FS, et al. Consumo e comportamento alimentar entre adolescentes brasileiros: Pesquisa Nacional de Saúde do Escolar (PeNSE), 2009. Ciênc Saúde Colet 2010; 15:3085-97.

4. Brug J, van Stralen MM, Te Velde SJ, Chinapaw MJM, De Bourdeaudhuij I, Lien N, et al. Differences in weight status andenergy-balance related behaviors among schoolchildren across Europe: the ENERGY-project. PLoS One 2012; 7:e34742.

5. Committee on Public Education. Children, adolescents, and television. Pediatrics 2001; 107:423-6.

6. Pimenta DV, Masson DF, Bueno MB. Analysis of food advertisements on television in children programs. J Health Sci Inst 2011; 29:52-5.

7. Britto SR, Viebig RF, Morimoto J. Analysis of food advertisements on cable television directed to children based on the food guide for the Brazilian population and current legislation. Rev Nutr 2016; 29:721-9.

8. Monteiro CA, Moubarac JC, Cannon G, Ng SW, Popkin B. Ultra-processed products are becoming dominant in the global food system. Obes Rev 2013; 14 Suppl 2:21-8.

9. Monteiro CA, Levy RB, Claro RM, Castro IRR, Cannon G. Increasing consumption of ultraprocessed foods and likely impact on human health: evidence from Brazil. Public Health Nutr 2010; 14:5-13.

10. Jull F, Martinez-Steele E, Parekh N, Monteiro CA, Chang VW Chang. Ultra-processed food consumption and excess weight among US adults. Br J Nutr 2018; 120:90-100.

11. Costa CS, Rauber F, Leffa PS, Sangalli CN, Campagnolo PDB, Vitolo MR. Ultra-processed food consumption and its effects on anthropometric and glucose profile: a longitudinal study during childhood. Nutr Metab Cardiovasc Dis 2019; 29:177-84.

12. Rauber F, Campagnolo PDB, Hoffman DJ, Vitolo MR. Consumption of ultra-processed food products and its effects on children's lipid profiles: a longitudinal study. Nutr Metab Cardiovasc Dis 2015; 25:116-22.

13. Rossi CE, Albernaz DO, Vasconcelos FAG, Assis MAA, Di Pietro PF, et al. Television influence on food intake and obesity in children and adolescents: a systematic review. Rev Nutr 2010; 23:607-20.

14. McGinnis JM, Gootman JA, Kraak VI. Food marketing to children and youth: threat or opportunity? Washington DC: National Academies Press; 2006. 
15. Arnas YA. The effects of television food advertisement on children's food purchasing requests. Pediatr Int 2006, 48:138-45.

16. Anderson GH, Khodabandeh S, Patel B, Luhovyy BL, Bellissimo N, Mollard RC. Mealtime exposure to food advertisements while watching television increases food intake in overweight and obese girls but has a paradoxical effect in boys. Appl Physiol Nutr Metab 2015; 40:162-7.

17. Boulos Rj, Vikre EK, Kanarek RB. ObesiTV: how television is influencing the obesity epidemic. Physiol Behav 2012; 107:146-53.

18. Martines RM, Machado PP, Neri DA, Levy RB, Rauber F. Association between watching TV while eating and children's consumption of ultra-processed foods in UK. Matern Child Nutr 2019; 15:e12819.

19. Parvanta SA, Brown JD, Du S, Zimmer CR, Zhao X, Zhai F. Television use and snacking behaviors among children and adolescents in China. J Adolesc Health 2010; 46:339-45.

20. Hulley SB, Cummings SR, Browner WS, Grady D, Hearst N, Newman TB. Designing clinical research: an epidemiologic approach. 2nd Ed. Philadelphia: Lippincott Williams \& Wilkins; 2001.

21. Instituto Brasileiro de Geografia e Estatística. Pesquisa de Orçamentos Familiares, 20082009: análise do consumo alimentar pessoal no Brasil. Rio de Janeiro: Instituto Brasileiro de Geografia e Estatística; 2011.

22. Instituto Brasileiro de Geografia e Estatística. Pesquisa de Orçamentos Familiares, 20082009: tabelas de composição nutricional dos alimentos consumidos no Brasil. Rio de Janeiro: Instituto Brasileiro de Geografia e Estatística; 2011.

23. Instituto Brasileiro de Geografia e Estatística. Pesquisa de Orçamentos Familiares, 20082009: tabela de medidas referidas para os alimentos consumidos no Brasil. Rio de Janeiro: Instituto Brasileiro de Geografia e Estatística; 2011.

24. Monteiro CA, Cannon G, Levy RB, Mourabac JC, Jaime P, Martins AP, et al. NOVA. A estrela brilha. World Nutrition 2016; 7:28-40.

25. Departamento de Atenção Básica, Secretaria de Atenção à Saúde, Ministério da Saúde. Protocolos do Sistema de Vigilância Alimentar e Nutricional: SISVAN na assistência à saúde. Brasília: Ministério da Saúde; 2008.

26. De Onis M, Onyango AW, Borghi E, Siyam A, Nishida C, Siekmann J. Development of a WHO growth reference for school-aged children and adolescents. Bull World Health Organ 2007; 85:660-7.

27. Maia EG, Costa BVL, Coelho FS, Guimarães js, Fortaleza RG, Claro RM. Análise da publicidade televisiva de alimentos no contexto das recomendações do Guia Alimentar para a População Brasileira. Cad Saúde Pública 2017; 33:e00209115.
28. Costa SMM, Horta PM, Santos LC. Analysis of television food advertising on children's programming on "free-to-air" broadcast stations in Brazil. Rev Bras Epidemiol 2013; 16:976-83.

29. Zhou Z, Diao Q, Shao N, Liang Y, Lin L, Lei $\mathrm{Y}$, et al. The frequency of unhealthy food advertising on Mainland Chinese television (TV) and children and adolescents' risk of exposure to them. PLoS One 2015; 10:e0128746.

30. Powell LM, Szczypka G, Chaloupka FJ. Trends in exposure to television food advertisements among children and adolescents in the United States. Arch Pediatr Adolesc Med 2010; 164:794-802.

31. Young B. Does food advertising make children obese? Int J Advert Mark Child 2003; 4:19-25.

32. Scapin T, Moreira CC, Fiates GMR. Children's influence over family food purchases of ultra processed foods: interference of nutritional status. Mundo Saúde 2015; 39:345-53.

33. Halford JCG, Boyland EJ, Cooper GD, Dovey TM, Smith CJ, Williams N, et al. Children's food preferences: effects of weight status, food type, branding and television food advertisements (commercials). Int J Pediatr Obes 2008; 3:31-8.

34. Harris JL, Bargh JA, Brownell KD. Priming effects of television food advertising on eating behavior. Health Psychol 2009; 28:404-13.

35. Canella DS, Levy RB, Martins AP. Ultra-processed food products and obesity in Brazilian households (2008-2009). PLoS One 2014; 9:e92752.

36. Organização Pan-Americana da Saúde. Recomendações da consulta de especialistas da Organização Pan-Americana da Saúde sobre a promoção e a publicidade de alimentos e bebidas não alcoólicas para crianças nas Américas. Washington DC: Organização Pan-Americana da Saúde; 2012.

37. Veerman JL, van Beeck EF, Barendregt JJ, Mackenbach JP. By how much would limiting TV food advertising reduce child hood obesity? Eur J Public Health 2009; 19:365-9.

38. Agência Nacional de Vigilância Sanitária. Consulta Pública no 71, de 10 de novembro de 2006. Proposta de Regulamento Técnico sobre oferta, propaganda, publicidade, informação e a outras práticas correlatas cujo objeto seja a divulgação ou promoção de alimentos com quantidades elevadas de açúcar, de gordura saturada, de gordura trans, de sódio e de bebidas com baixo teor nutricional, quaisquer que sejam as formas e meios de sua veiculação. Diário Oficial da União 2006; 13 nov.

39. Henriques P, Sally EO, Burlandy L, Beiler RM. Regulation of publicity for children's food as a strategy for promotion of health. Ciênc Saúde Colet 2012; 17:481-90. 


\section{Resumo}

O estudo teve como objetivo verificar a associação entre o hábito de comprar produtos alimentícios anunciados na televisão e o consumo de determinados alimentos, em uma amostra transversal de alunos do quarto ano do Ensino Fundamental na rede municipal de Belo Horizonte, Minas Gerais, Brasil. Foram analisados dados antropométricos, o hábito de comprar alimentos e bebidas anunciados na televisão e o consumo de alimentos específicos (dois recordatórios alimentares de 24 horas). Foram construídos modelos de regressão logística ajustados para sexo, idade, calorias na dieta, estado nutricional e privação social da região de residência. O estudo avaliou 797 crianças, com média de idade de 9,81 (0,59) anos, 50,7\% das quais do sexo feminino e 32,4\% com sobrepeso. A prevalência do hábito de comprar alimentos anunciados na televisão foi de 43,1\%. Entre estas crianças, 99,3\% relatavam alimentos ultraprocessados de acordo com a classificação proposta por Monteiro et al. (2016), com destaque para as bebidas lácteas $(12,1 \%)$, biscoitos industrializados $(11,5 \%)$ e doces (9,5\%). O hábito de comprar produtos alimentícios anunciados na TV aumentava o consumo de alimentos ultraprocessados $(O R=1,92$; IC95\%: 1,06-3,46). Não houve associação entre esse hábito e o consumo de alimentos minimamente processados ou processados $(p<0,05)$. Os achados podem contribuir para o debate sobre politicas regulatórias para a propaganda de produtos alimentícios, além de assistir no desenvolvimento de intervenções nutricionais efetivas entre escolares, o que deve envolver ações educacionais integradas, com a participação das crianças e seus pais.

Consumo de Alimentos; Publicidade de Alimentos; Criança; Televisão

\section{Resumen}

El objetivo de este estudio fue verificar la asociación del hábito de comprar comida anunciada en la televisión y el consumo de comida. Este estudio trasversal se desarrolló con estudiantes del cuarto año en la red municipal de escuelas primarias en Belo Horizonte, Minas Gerais Brasil. Se investigaron datos antropométricos, el hábito de comprar comida/bebidas que aparecen en anuncios de televisión y consumo de comida (dos recordatorios de 24-horas). Se construyeron modelos de regresión logística, ajustados por sexo, edad, calorías de la dieta, estatus nutricional, y carestía social de la región de residencia. Se evaluaron a un total de 797 niños, con una media de 9,81 $(0,59)$ años de edad, 50,7\% mujeres y un 32,4\% con sobrepeso. La prevalencia del hábito de comprar comida anunciada en televisión fue de un 43,1\%. Entre estos, un 99,3\% se refirió a comidas ultraprocesadas según la clasificación propuesta por Monteiro et al. (2016), con énfasis en bebidas lácteas (12.1\%), galletas industrializadas (11.5\%) y golosinas (9.5\%). El hábito de comprar comida anunciada aumenta la oportunidad de consumir comida ultraprocesada $(O R=1,92$; IC95\%: 1,06-3,46). No hubo asociación entre este hábito y el consumo de comidas minimamente procesadas y procesadas $(p<0,05)$. El hábito de comprar comida anunciada en televisión lleva a un consumo más alto de productos procesados. Tal vez los resultados de este estudio contribuyan al debate de la política regulatoria en la publicidad de comida, así como también al apoyo en el desarrollo de intervenciones efectivas nutricionales entre escolares, que implicarían acciones integradas educativas, involucrando a los niños y a sus respectivos progenitores.

Consumo de Alimentos; Publicidad de Alimentos; Niño; Televisión
Submitted on 14/May/2019

Final version resubmitted on 26/Dec/2019

Approved on 15/Jan/2020 